THE GREAT PLAGUE 



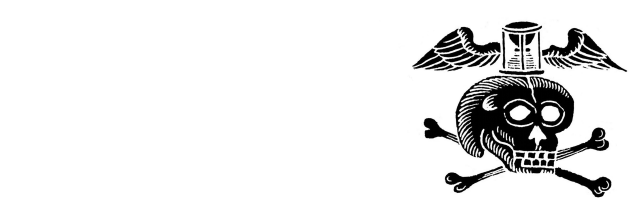

\section{THE GREAT PLAGUE}

A PEOPLE'S HISTORY

Evelyn Lord 
Copyright (C) 2014 Evelyn Lord

All rights reserved. This book may not be reproduced in whole or in part, in any form (beyond that copying permitted by Sections 107 and 108 of the U.S. Copyright Law and except by reviewers for the public press) without written permission from the publishers.

For information about this and other Yale University Press publications, please contact: U.S.Office: sales.press@yale.edu www.yalebooks.com

Europe Office: sales@yaleup.co.ukｗww.yalebooks.co.uk

Set in Adobe Caslon Pro by IDSUK (DataConnection) Ltd

Printed in Great Britain by TJ International Ltd, Padstow, Cornwall

Library of Congress Cataloging-in-Publication Data

Lord, Evelyn.

The Great Plague: a people's history/Evelyn Lord.

pages $\mathrm{cm}$

Includes bibliographical references.

ISBN 978-0-300-17381-9 (cl : alk. paper)

1. Plague-England-Cambridge-History. 2. Cambridge (England)—History.

3. University of Cambridge-History. I. Title.

RC178.G72E64 2014

942.1'066-dc23

2013041977

A catalogue record for this book is available from the British Library.

1098766543221 
To Edward, Gabriel, Natascha and Roderick Lord, and in memory of Katie Lord with love 
